\title{
Chromosome comparison between two species of Phyllostomus (Chiroptera - Phyllostomidae) from Eastern Amazonia, with some phylogenetic insights
}

\author{
Luís R.R. Rodrigues ${ }^{1}$, Regina M.S. Barros ${ }^{1}$, Maria de Fátima L. Assis ${ }^{1}$, Suely A. Marques-Aguiar ${ }^{2}$, \\ Julio C. Pieczarkal and Cleusa Y. Nagamachi ${ }^{1}$
}

\begin{abstract}
The karyotypes of Phyllostomus discolor and P. hastatus from Eastern Amazonia were studied by G-, C-, G/C sequential and AgNOR techniques. Both species presented $2 \mathrm{n}=32$, with the autosome complement composed of 30 bi-armed in $P$. discolor and 28 biarmed plus 1 acrocentric in $P$. hastatus. In both species, the $\mathrm{X}$ chromosome is medium submetacentric while the $\mathrm{Y}$ is minute acrocentric. The present study found only one difference between the karyotypes of $P$. discolor and $P$. hastatus: the smallest autosome (pair 15) is bi-armed in discolor and acrocentric in hastatus, a result best explained by pericentric inversion. The C-banding revealed constitutive heterochromatin only at the centromeric regions of all chromosomes, with the NOR site located at the distal region of short arm of pair 15 , in both species. The taxon $P$. discolor is considered primitive for genus Phyllostomus and the bi-armed form of pair 15 is the assumed primitive condition which, rearranged by a pericentric inversion originated the acrocentric form found in $P$. hastatus.
\end{abstract}

\section{INTRODUCTION}

The neotropical bat genus Phyllostomus (Chiroptera - Phyllostomidae) traditionally includes four species: $P$. hastatus, P. discolor, P. elongatus and P. latifolius (Valdez, 1970). The genera Phyllostomus and Phylloderma, solely comprising the species Phylloderma stenops, are closely related by morphology (Williams and Genoways, 1980), karyotypes (Baker, 1973, 1979) and albumin data (Honeycutt and Sarich, 1987). Baker et al. (1988) suggested the inclusion of Phylloderma stenops in Phyllostomus. Evidence of strong affinity between Phyllostomus and Phylloderma was reinforced by cytochrome-b sequence analysis (Van den Bussche and Baker, 1993). In this paper, by adding Phyllostomus stenops (Baker et al., 1988), we increased to five the number of species in the genus Phyllostomus.

Widely distributed throughout in the Central and South America, P. hastatus occurs from Honduras to Southeastern Brazil; P. discolor occurs from Mexico to Argentina while P. elongatus is restricted to South America in Colombia, Venezuela, the Guianas, Brazil, Ecuador, Peru and Bolivia; $P$. latifolius was registered in the Kanuko Mountains, of Guyana and in Suriname whereas P. stenops is found from Mexico to Northern Bolivia and Southeastern Brazil (Valdez, 1970; Jones and Carter, 1976; Honeycutt et al., 1980; Wilson and Reeder, 1993).

Karyotypic studies in Phyllostomus have demonstrated that all species possess $2 \mathrm{n}=32 ; P$. discolor has $\mathrm{FN}$ $=60$ while $P$. hastatus, $P$. elongatus, $P$. stenops and $P$. latifolius have FN = 58 (Baker, 1973, 1979; Honeycutt et al., 1980). Chromosome comparisons by G-banding between $P$. discolor and $P$. hastatus from Central America (Patton and Baker, 1978) have demonstrated that only the smallest autosome (pair 15), a chromosome metacentric in $P$. discolor and acrocentric in $P$. hastatus, underwent rearrangement after divergence of the two species. A similar result was found in specimens from Southeastern Brazil (Varella-Garcia et al., 1989). C-banding studies revealed constitutive heterochromatin only at centromeric regions in P. hastatus, P. discolor and P. elongatus (Baker, 1979; Varella-Garcia et al., 1989). Ag-NOR staining identified NOR site, located only on chromosome 15 in P. hastatus and $P$. discolor (Morielle and Varella-Garcia, 1988).

According to Patton and Baker (1978), the karyotype of Macrotus waterhousii $(2 \mathrm{n}=46, \mathrm{FN}=60)$ is considered primitive to the family Phyllostomidae. Phyllostomus hastatus, $P$. discolor, Mimon crenulatum and Tonatia minuta are associated by five synapomorphic chromosome rearrangements: four Robertsonian fusions (18/3, 8/9, 17/ 12 and 29/27) and one inversion (4/5 inv.). Phyllostomus and Mimon share three additional synapomorphic fusions (22/13, 14a/21 and 28/30). The monophyly of Phyllostomus was established but the interspecific relationships remain unresolved (Honeycutt and Sarich, 1987; Baker et al., 1988; Van Den Bussche and Baker, 1993).

The Amazonian Region bat fauna is the world's richest (Findley, 1993). Despite this, few studies have been made of bats from that region, at least from Brazilian Amazonia. This study presents a chromosome comparison between Phyllostomus discolor and P. hastatus, through G-band-

${ }^{1}$ Departamento de Genética, CCB, Universidade Federal do Pará, 66075-900 Belém, PA, Brasil. 
ing, C-banding, sequential G/C-banding and NOR staining patterns, in specimens exclusively from Brazilian Amazonia and discusses the phylogeny of genus Phyllostomus from the chromosomal standpoint.

\section{MATERIAL AND METHODS}

The sample included 3 specimens of Phyllostomus discolor $(1 \mathrm{M}, 2 \mathrm{~F})$ from Belém ( $\left.1^{\circ} 11^{\prime} \mathrm{S}, 48^{\circ} 29^{\prime} \mathrm{W}\right)$, and 4 P. hastatus (1M, 3F) from Peixe-Boi ( $\left.1^{\circ} 11^{\prime} \mathrm{S}, 47^{\circ} 19^{\prime} \mathrm{W}\right)$, both in Pará State, Brazil. All specimens were taken from natural populations and collected with mist nets; voucher specimens are found in the mammal collections of the Emílio Goeldi Museum in Pará. Access numbers are: 26328, 26329 and 26330 for $P$. discolor and 26331, 26332, 26333 and 26334 for $P$. hastatus. Metaphase spreads were got with fibroblast cultures from ear biopsies and bone marrow preparations (Baker and Qumsiyeh, 1988). Slides were prepared using air-drying method and G-bands obtained by trypsin treatment (Scheres, 1972), C-bands were performed according to Sumner (1972), sequential G/C-banding followed both techniques (some metaphases were G-banded, photographed and later submitted to a C-banding process), and Ag-NOR staining followed Howell and Black (1980).

\section{RESULTS}

The karyotype of Phyllostomus discolor possesses $2 \mathrm{n}=32$ and $\mathrm{FN}=60$; the autosome complement is composed of 15 bi-armed pairs, while that $P$. hastatus has $2 \mathrm{n}=$ $32, \mathrm{FN}=58$, with 14 bi-armed plus one acrocentric pair. In both species, the $\mathrm{X}$ chromosome is medium submetacen- tric and the $\mathrm{Y}$ is minute acrocentric. Figures 1 and 2 show, respectively, the G- and C-bands representative of $P$. hastatus and similar those of $P$. discolor. C-banding revealed constitutive heterochromatin restricted to the pericentromeric region of all chromosomes.

Comparative analysis of G-banding pattern between $P$. discolor and P. hastatus shows that both species conserved all chromosomes without rearrangements, except for chromosome 15, altered by pericentric inversion (Figure 3 ). Both species presented Ag-NOR labelling at a distal region of pair 15 (Figure 3d).

\section{DISCUSSION}

Karyotypes of $P$. discolor and $P$. hastatus from Eastern Amazonia are identical to those described for Central American specimens (Patton and Baker, 1978), and Southeastern Brazil (Morielle and Varella-Garcia, 1988; VarellaGarcia et al., 1989). Our results corroborate the hypothesis that Phyllostomus has a conservative rate of chromosomal evolution, in contrast to other widespread bat genera, e.g., Tonatia and Micronycteris that present a high rate of chromosomal evolution (Baker and Bickham, 1980).

$P$. discolor and $P$. hastatus differ cytogenetically by a single pericentric inversion in chromosome 15 , probably derived by fusion of acrocentrics 28 and 30 from Macrotus waterhousii (Patton and Baker, 1978). This chromosome, a small metacentric in $P$. discolor, is acrocentric in $P$. hastatus, P. elongatus, P. stenops and P. latifolius (Baker, 1973, 1979; Honeycutt et al., 1980). Considering that $P$. discolor is primitive to genus Phyllostomus (Valdez, 1970; Honeycutt and Sarich, 1987; Baker et al., 1988), and shares

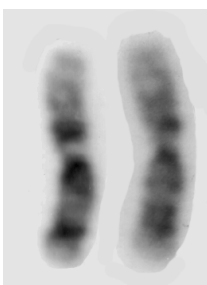

1

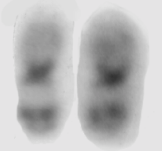

8

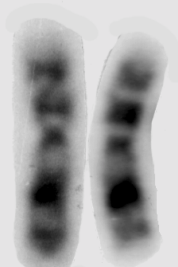

2

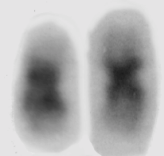

9

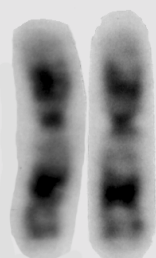

3

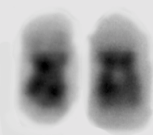

10

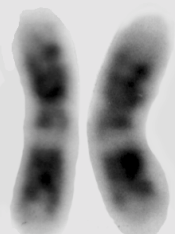

4

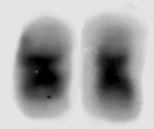

11

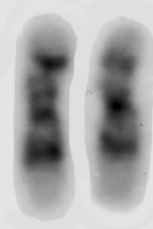

5

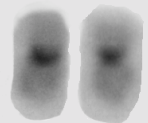

12

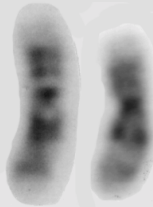

6

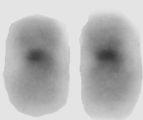

13

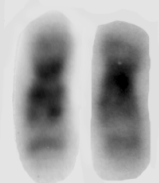

7

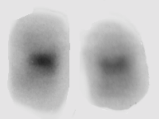

14

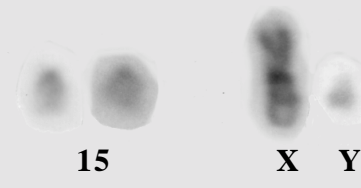

Figure 1 - G-banding pattern of Phyllostomus hastatus. 


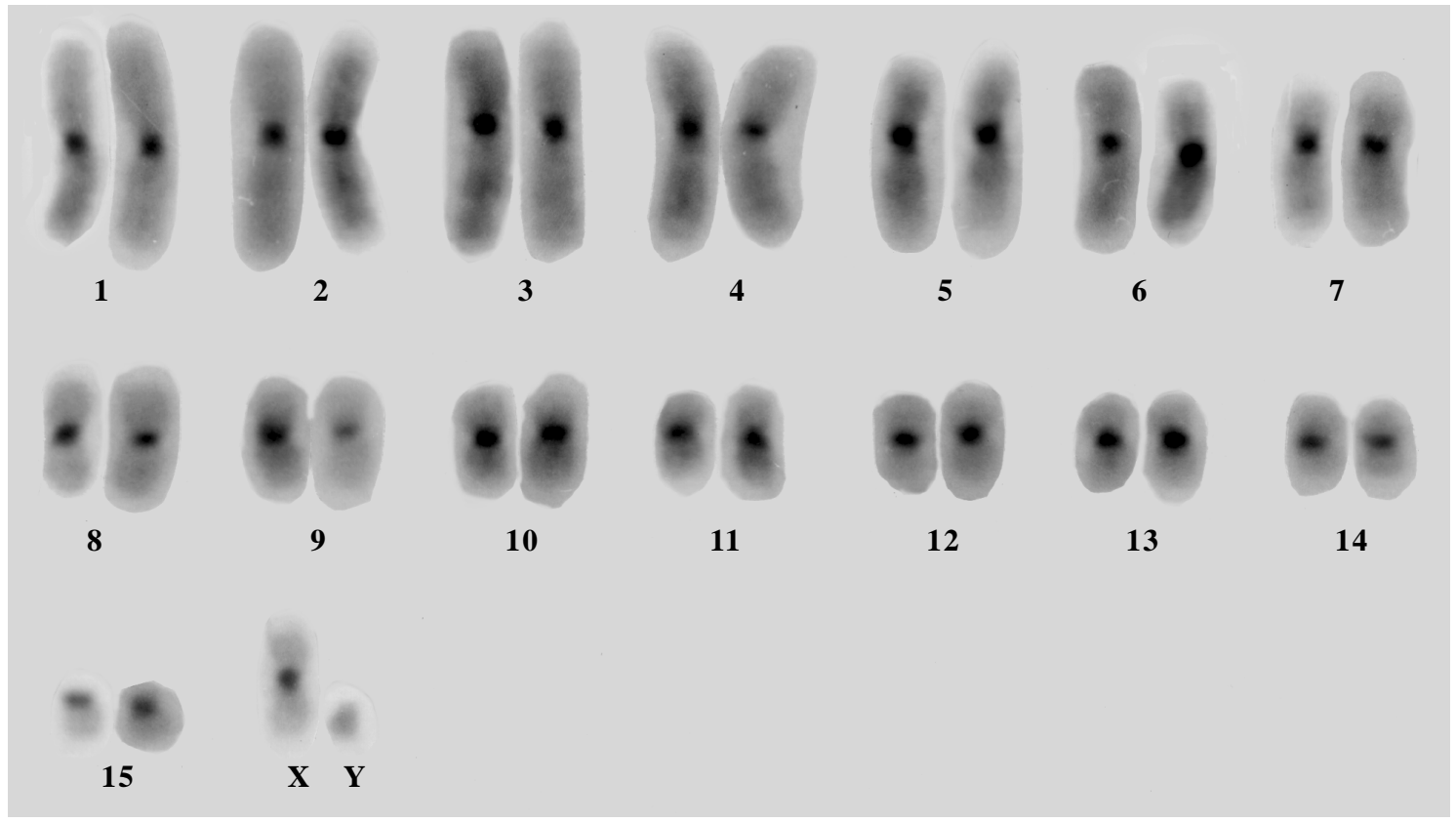

Figure 2 - C-banding pattern of Phyllostomus hastatus.

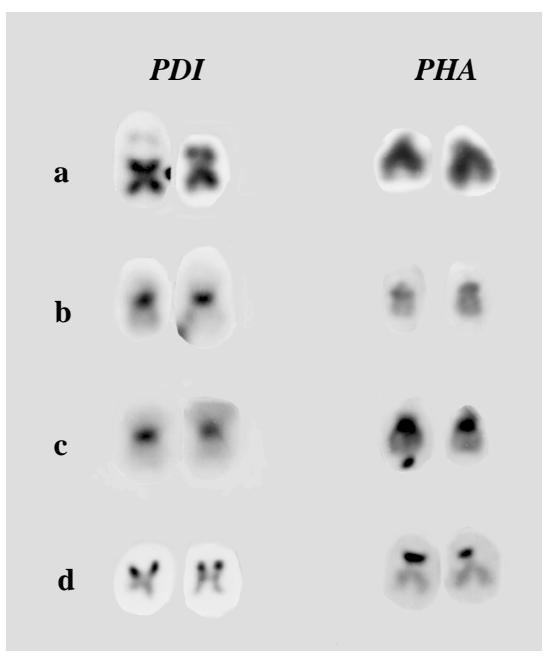

Figure 3 - Pair 15 of Phyllostomus discolor (PDI) and P. hastatus (PHA). a) Giemsa stained, b) G-banded, c) C-banded and d) Ag-NOR stained.

with Mimon crenulatum the metacentric chromosome 15 (Patton and Baker, 1978), the apparently derived acrocentric chromosome 15 is shared by P. hastatus, P. elongatus, P. stenops and P. latifolius.

Chromosome 15 of $P$. discolor presents the NOR on the distal region of one arm, while it appears on the distal region of a short arm in the 15 of $P$. hastatus. Therefore, the chromosome portion involved in pericentric inversion seems unlikely to contain DNAr sequences, because of the distal position of the NOR site. In general, few species of the family Phyllostomidae have been studied by Ag-NOR staining (Baker, 1979). In the specific case of Phyllostomus, NOR studies are needed to verify if: 1) $P$. elongatus and $P$. stenops present NORs at distal regions of the short arm of chromosome 15 as in P. hastatus, 2) Mimon crenulatum has NOR sites on chromosome 15 as in P. discolor, and 3) Macrotus waterhousii presents NORs in the acrocentric 28 or 30. This information will increase understanding of chromosomal evolution in the genus Phyllostomus.

Interspecific relationships in the genus Phyllostomus have been difficult to clarify. Using morphological characters, Valdez (1970) proposed a close relationship between $P$. elongatus and P. latifolius. In contrast, albumin distance analysis (Honeycutt and Sarich, 1987) indicated a closer connection between $P$. hastatus and $P$. elongatus, joined by $P$. stenops in one group while $P$. discolor and $P$. latifolius emerged at the cladogram base. The allozymic data from Baker et al. (1988), while not adequately resolving interspecific relationships in Phyllostomus, suggested that the five species diverged at approximately the same time. Phylogenetic analysis with cytochrome-B sequence (Van Den Bussche and Baker, 1993) confirmed the hastatuselongatus association suggested by Honeycutt and Sarich (1987), and suggested that $P$. discolor is sister taxa to hastatus-elongatus, with P. latifolius joining this group and P. stenops at the root of the tree.

We suggest a chromosomal phylogeny for genus Phyllostomus (Figure 4), based on the data (see references: Patton and Baker, 1978; Baker, 1979; Honeycutt et al., 1980; Honeycutt and Sarich, 1987; Baker et al., 1988; Van Den Bussche and Baker, 1993) and assuming that: a) P. dis- 


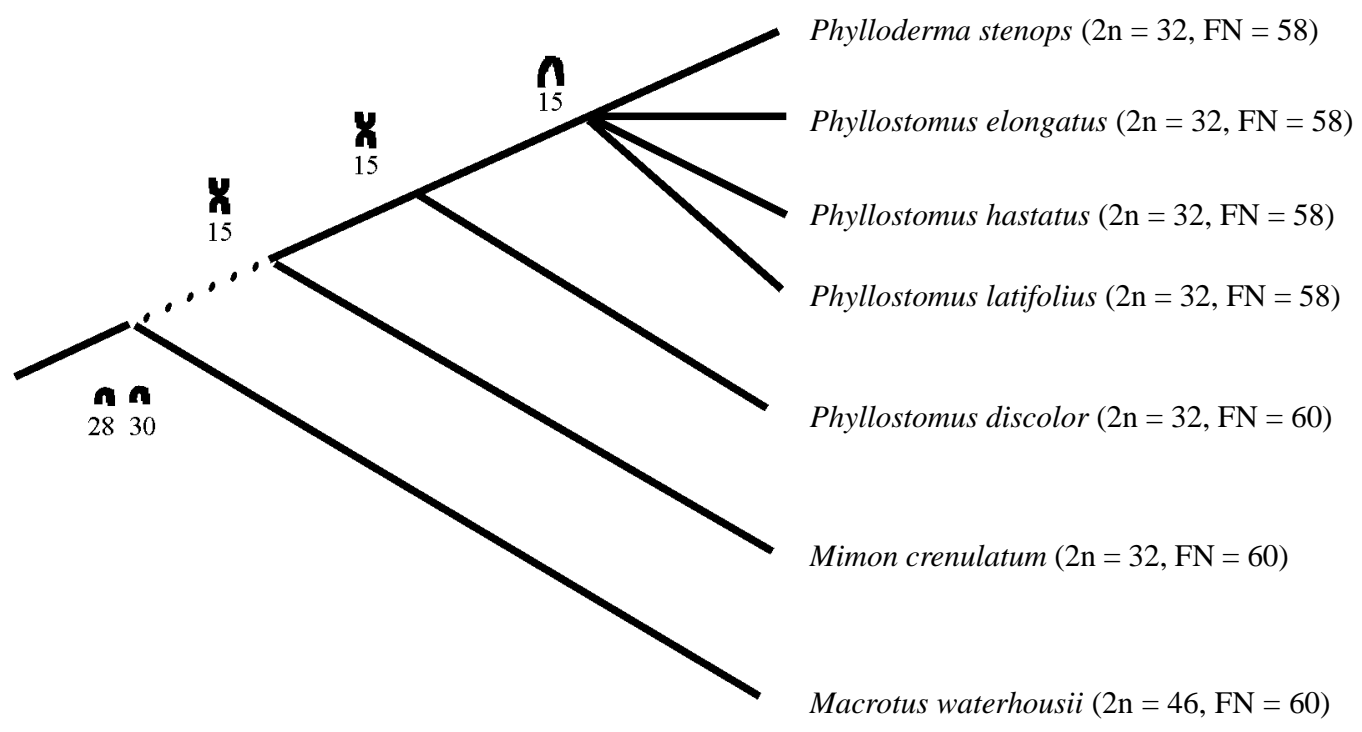

Figure 4 - Chromosomal phylogeny of the genus Phyllostomus based on literature data.

color is primitive to Phyllostomus, b) the bi-armed chromosome 15 shared with Mimon crenulatum arose by fusion between two acrocentrics (28 and 30) from Macrotus waterhousii, followed by pericentric inversion in the ancestral lineage of $P$. hastatus, $P$. elongatus, $P$. latifolius and $P$. stenops.

Cytogenetic data are compatible with the phylogeny based on albumin data, proposed by Honeycutt and Sarich (1987). On the other hand, from the cytogenetic standpoint, the hypothesis based on cytochrome-B (Van Den Bussche and Baker, 1993) is less parsimonious because if the biarmed form of chromosome 15 is primitive, then the derived form (acrocentric) would have twice evolved: once at lineage $P$. stenops, again at lineage $P$. latifolius and the finally at lineage hastatus-elongatus.

Additional studies are need for clarifying the interspecific relationships in the genus Phyllostomus. Special attention should be given to Ag-NOR staining or DNAr hybridization studies in Mimon crenulatum, Phyllostomus stenops and P. elongatus to ascertain the supposed homeology of chromosome 15.

\section{ACKNOWLEDGMENTS}

We thank CAPES, CNPq, FINEP and PROPESP-UFPA, Brazil, for financial support. We also thank the students and technicians from Laboratório de Citogenética-UFPA and Emílio Goledi Museum who contributed to this research, especially to the Chiroptera Team (Carol, Renata, Nelson, Adailton and Ciane).

\section{RESUMO}

Os cariótipos de Phyllostomus discolor e P. hastatus da Amazônia oriental são estudados por bandeamentos G, C, G/C sequencial e coloração Ag-NOR. Ambas as espécies apresentaram $2 \mathrm{n}=32$, sendo o complemento autossômico composto por 15 pares bi-armed em $P$. discolor e 14 bi-armed mais 1 par acrocêntrico em $P$. hastatus. O cromossomo X é um submetacêntrico médio e o Y é um pequeno acrocêntrico em ambas as espécies. O presente estudo encontrou apenas uma diferença entre os cariótipos de $P$. discolor e P. hastatus: o menor autossomo (par 15) é metacêntrico em discolor e acrocêntrico em hastatus. Este resultado é melhor explicado por uma inversão pericêntrica. O bandeamento $\mathrm{C}$ revelou heterocromatina constitutiva na região centromérica de todos os cromossomos, e os sítios NOR foram localizados na região distal do par 15 , em ambas as espécies. O táxon P. discolor é considerado primitivo para o gênero Phyllostomus e supõe-se que a forma metacêntrica do par 15 seja a condição primitiva, que foi rearranjada por uma inversão pericêntrica, originando a forma acrocêntrica encontrada em $P$. hastatus.

\section{REFERENCES}

Baker, R.J. (1973). Comparative cytogenetics of the New World leaf-nosed bats (Phyllostomidae). Period. Biol. 75: 37-45.

Baker, R.J. (1979). Karyology. In: Biology of Bats of the New World Family Phyllostomatidae. Part III (Baker, R.J., Jones, J.K. and Carter, D.C., eds.). Special Publication of the Museum of Texas Tech. University, Lubbock, pp. 107-155.

Baker, R.J. and Bickham, J.W. (1980). Karyotypic evolution in bats: Evidence of extensive and conservative chromosomal evolution in closely related taxa. Syst. Zool. 29: 239-253.

Baker, R.J. and Qumsiyeh, M.B. (1988). Methods in chiropteran mitotic chromosomal studies. In: Ecological and Behavioral Methods for the Study of Bats (Kunz, T.H., ed.). Smithsonian Institution Press, Washington, pp. 425-435

Baker, R.J., Dunn, C.G. and Nelson, K. (1988). Allozymic study of the relationships of Phylloderma and four species of Phyllostomus. Occas. Pap. Mus. Texas Tech. Univ. 125: 1-14.

Findley, J.S. (1993). Bats: A Community Perspective. Cambridge University Press, Cambridge, pp. 167

Honeycutt, R.L. and Sarich, V. (1987). Monophyly and molecular evolution 
within three phyllostomid bat genera. J. Mamm. 68: 518-525.

Honeycutt, R.L. Baker, R.J. and Genoways, H.H. (1980). Results of the Alcoa Foundation-Suriname Expeditions. III. Chromosomal data for bats (Mammalia: Chiroptera) from Suriname. Ann. Carnegie Mus. 49: 237-249.

Howell, W.M. and Black, D.A. (1980). Controlled silver-staining of nucleolar organizer regions with protective colloidal developer: a 1-step method. Experientia 36: 1014-1015.

Jones Jr., J.K. and Carter, D.C. (1976). Annotated Checklist, with keys to subfamilies and genera. In: Biology of Bats of the New World Family Phyllostomatidae. Part I (Baker, R.J., Jones Jr., J.K. and Carter, D.C., eds.). Special Publication of the Museum of Texas Tech. University, Lubbock, 7-38.

Morielle, E. and Varella-Garcia, M. (1988). Variability of nucleolus organizer regions in Phyllostomid bats. Rev. Bras. Genet. 11: 853-871

Patton, J.C. and Baker, R.J. (1978). Chromosomal homology and evolution of phyllostomatoids bats. Syst. Zool. 27: 449-462.

Scheres, J.M.J.C. (1972). Identification of two Robertsonian translocations with Giemsa banding technique. Humangenetik 15: 253-256.
Sumner, A.T. (1972). A simple technique for demonstrating centromeric heterochromatin. Exp. Cell Res. 75: 304-306.

Valdez, R. (1970). Taxonomy and geographic variation of the bats of the genus Phyllostomus. Doctoral thesis, Texas A\&M University, Texas.

Van Den Bussche, R.A. and Baker, R.J. (1993). Molecular phylogenetics of the New World bat genus Phyllostomus based on cytochrome B DNA sequence variation. J. Mamm. 74: 793-802.

Varella-Garcia, M., Morielle-Versute, E. and Taddei, V.A. (1989). A survey of cytogenetic data on Brazilian bats. Rev. Bras. Genet. 12: 761-793.

Williams, S.L. and Genoways, H.H. (1980). Results of the Alcoa Foundation-Suriname expeditions. II. Additional records of the bats (Mammalia: Chiroptera) from Suriname. Ann. Carnegie Mus. 15: 213-236.

Wilson, D.E. and Reeder, D.M. (1993). Mammal Species of the World: a Taxonomic and Geographic Reference. 2nd edn. Smithsonian Institution Press in association with the American Society of Mammalogists, Washington, pp. 1206.

(Received August 20, 1999) 
